\title{
IMPLEMENTASI PENDIDIKAN KARAKTER \\ DALAM PERSPEKTIF DI SEKOLAH
}

Tutuk Ningsih

Dosen Jurusan Tarbiyah STAIN Purwokerto

\begin{abstract}
Character education requires a basis of conceptualization of the character and moral comprehensively by cultural basis which is clear and focused. To form students who have a positive character, it should also require the environment which has character. Person's behavior is determined by the environment it means someone is going to be a person who has character if grown in environments characterized. That's what needs to be built the basic character which is from the moral values of humanity in the community, both as individuals or groups. Education establishes good character and personality intact someone, besides every parent in the family, it can also be done through moral guidance in schools, moral guidance should be designed and managed in such a way so that in the learning process there is also the process of establishing good attitudes and behavior, in practising character values can be taught through activities intracurricular (integrated subjects) and extracurricular activities so that students can translate in real behavior. Character education is everything is done by the teacher, which could affect the character of students. Teacher helps forming the character of students. This includes how the implementation of exemplary character education in the perspective at schools especially teacher behavior, the way teachers speak or deliver material, how teacher tolerates and other related matters. Character education is an investment system of values character to the citizens of the school which includes the components of knowledge, awareness or volition/ will, and action to implement those values. Implementation can be realized through the methods: (1) know how to lose, (2) understand the difference between winning and success, (3) respect for others, (4) work with others, (5) demonstrated integrity, (6) show self-confidence, and, (7) give return.

Keywords: Implementation, character education, school.
\end{abstract}

\section{Pendahuluan}

Pendidikan karakter sebagai sebuah pedagogi memberikan perhatian pada tiga hal penting bagi pertumbuhan manusia, yaitu perkembangan kemampuan kodrati manusia sebagaimana dimiliki secara berbeda oleh 
tiap individu (naturalis). Dalam mengembangkan kemampuan kodrati ini manusia tidak dapat mengabaikan relasi negatifnya dengan lingkungan sosial (Rosseau), dan dalam relasi antara individu dan masyarakat ini, manusia mengarahkan diri pada nilai-nilai (di antaranya adalah Foerster, Marx, Kohlberg dan Dithrey). Dengan demikian siswa membutuhkan pendidikan karakter yang akan membentuk karakter positif.

Pendidikan karakter penting karena hasil pendidikan belum sepenuhnya sesuai dengan tujuan pendidikan, apalagi melihat fenomena di kalangan remaja. Dekadansi moral semakin meningkat disebabkan pendidikan tidak menyentuh aspek afektif, sehingga karakter siswa tidak mencerminkan manusia yang memiliki karakter baik, yang ada hanyalah manusia yang cerdas tetapi memiliki emosi tumpul. Untuk itulah guru perlu mendidik siswa agar memiliki karakter positif.

Menurut Thornas Lickona (2004), karakter terdiri dari 3 bagian yang saling terkait, yaitu pengetahuan tentang moral (moral knowing), perasaan (moral feeling), dan perilaku bermoral (moral behavior). Karakter yang baik terdiri dari mengetahui kebaikan (knowing the good), mencintai atau menginginkan kebaikan (loving or desiring the good), dan melakukan kebaikan (acting the good). Oleh karena itu, cara membentuk karakter yang efektif adalah dengan melibatkan ketiga aspek tersebut. Selain itu, karakter adalah otot-otot yang sudah terbentuk, yang berkembang melalui proses panjang latihan dan kedisiplinan yang dilakukan setiap hari. Ibaratnya seperti seorang binaragawan yang ototnya terbentuk melalui proses latihan dan kedisiplinan tinggi sehingga "otot-otot"nya kokoh terbentuk.

Pendidikan karakter di sekolah yang berhasil sangat tergantung dari komitmen kepala sekolah yang mempunyai visi ingin membangun karakter siswa di sekolahnya. Misalnya, sebuah sekolah dapat mencantumkan visi "Membina dan mengembangkan siswa berkarakter yang sesuai dengan nilai-nilai luhur kepribadian bangsa". Visi tersebut harus disadari oleh seluruh guru dan orangtua, yang semuanya ini sangat tergantung pada kemampuan Kepala Sekolah untuk mensosialisasikan visinya. Selain itu, visi tersebut diluangkan dalam misi yang jelas, dan strategi apa yang dapat digunakan untuk mencapai visi tersebut.

Pendidikan karakter adalah sebuah usaha untuk mendidik anak-anak agar dapat mengambil keputusan dengan bijak dan mempraktekannya dalam 
kehidupan sehari-hari sehingga mereka dapat memberikan kontribusi yang positif kepada lingkungannya. Nilai-nilai karakter yang perlu ditanamkan kepada anak-anak adalah nilai-nilai universal yang mana seluruh agama, tradisi, dan budaya pasti menjunjung tinggi nilai-nilai tersebut. Nilai-nilai universal ini harus dapat menjadi perekat bagi seturuh anggota masyarakat walaupun berbeda latar betakang budaya, suku, dan agama.

Dalam masyarakat yang heterogen seperti di Indonesia, nilai-nilai karakter yang ditanamkan harus dapat menjadi common denominator (dasar kesamaan nilai) yang akan menjadi perekat pada elemen-elemen masyarakat yang berbeda, sehingga masyarakat dapat hidup berdampingan secara damai dan tertib yang akhirnya menciptakan suasana sinergi yang sangat produktif bagi kemajuan bangsa.

\section{Pengertian Karakter}

Bung Karno sebagai pendiri negara Indonesia pernah memposisikan pendidikan karakter sebagai bagian dari kegiatan yang strategis dalam perubahan bangsa secara kultural. Ungkapan Bung Karno tersebut dikemukakan dalam Toho Cholik Mutohir (2002: 8) bahwa:

“... character and national building penting sekali, karena merupakan dasar dari segala kehidupan bangsa Indonesia. Mau membangun negara dan bangsa diperlukan karakter, akhlak yang mulia dan mental yang baik. Sesuatu bangsa tidak akan membangun apa pun dengan karakter, mental yang bobrok, karakter dan mental yang sudah rusak. Maka dari itu pembangunan karakter adalah penting sekali, sukar sekali dan memerlukan waktu yang tidak pendek, memerlukan waktu yang lama".

Secara mendasar Lickona (1991: 51), menyatakan bahwa "good character consist of knowing the good, desiring the good, and doing the good habits of the mind, habits of the heart, and habus of action". Oleh karena itu, individu yang mampu mengaplikasikan pernyataan tersebut tentu akan dapat menentukan tindakan mana yang baik dan benar serta tindakan mana yang buruk dan jelek. Selanjutnya, dalam membahas karakter seseorang akan selalu terkait dengan konsep nilai (value). Menurut Weinberng dan Gould (2003: 540), nilai adalah "an enduring belief that a specific mode of conduct or end-state of existence is personally or socially preferable to on opposite or or converse mode of conduct or end-state of existence." 
Dari pengertian tersebut, ada dua hal yang perlu diperhatikan mengenai nilai, yaitu: (1) nilai merupakan suatu keyakinan yang relatif menetap pada jiwa seseorang; (2) eksistensi nilai seseorang sangat dipengaruhi oleh kondisi sosial budaya di mana seseorang berada. Dengan demikian, kondisi sosial budaya memberikan kontribusi yang besar terhadap konsep penanaman nilai-nilai pada diri seseorang. Selain itu, kebiasaan-kebiasaan (habituasi) yang tumbuh subur dalam masyarakat juga merupakan wahana proses terbentuknya karakter seseorang.

Karakter merupakan sebuah konsep moral yang tersusun dari sejumlah karakteristik yang juga dapat dibentuk melalui aktivitas olahraga. Setidaknya ada nilai-nilai baik yang bisa dibentuk lewat aktivitas olahraga, antara lain: rasa terharu (compassion), keadilan (fairness), sikap sportif (sport-personship), dan integritas (integrity) (Weinberg dan Gould, 2003: 527). Semua nilai itu ditanamkan melalui ketaatan (kepatuhan) seseorang dalam berkompetisi sesuai peraturan permainan yang berlaku pada cabang olahraga yang digelutinya. Di dalam peraturan permainan melekat semangat keadilan, sportivitas, dan tuntutan kejujuran para pelaku olahraga saat berlatih maupun bertanding. Hal itulah yang mampu menimbulkan rasa terharu (empati) antar pelakunya. Kondisi seperti itulah yang mampu membentuk karakter seseorang yang aktif dalam olahraga dengan melaksanakan kompetisi menurut peraturan permainan yang berlaku.

Perkembangan dan terbentuknya karakter seseorang dipengaruhi oleh kemampuan kognisi dan daya tangkap seseorang dalam berinteraksi dengan lingkungan sosial budaya. Oleh karena itu, karakter seseorang terbentuk bukan saja karena menirukan dari pengamatan, tetapi juga dapat diajarkan melalui situasi olahraga, latihan, dan aktivitas fisik (Weinberg dan Gould, 2003: 533).

Pada Gambar 1 di bawah ini memperlihatkan implementasi pendidikan karakter di sekolah sebagai berikut. 


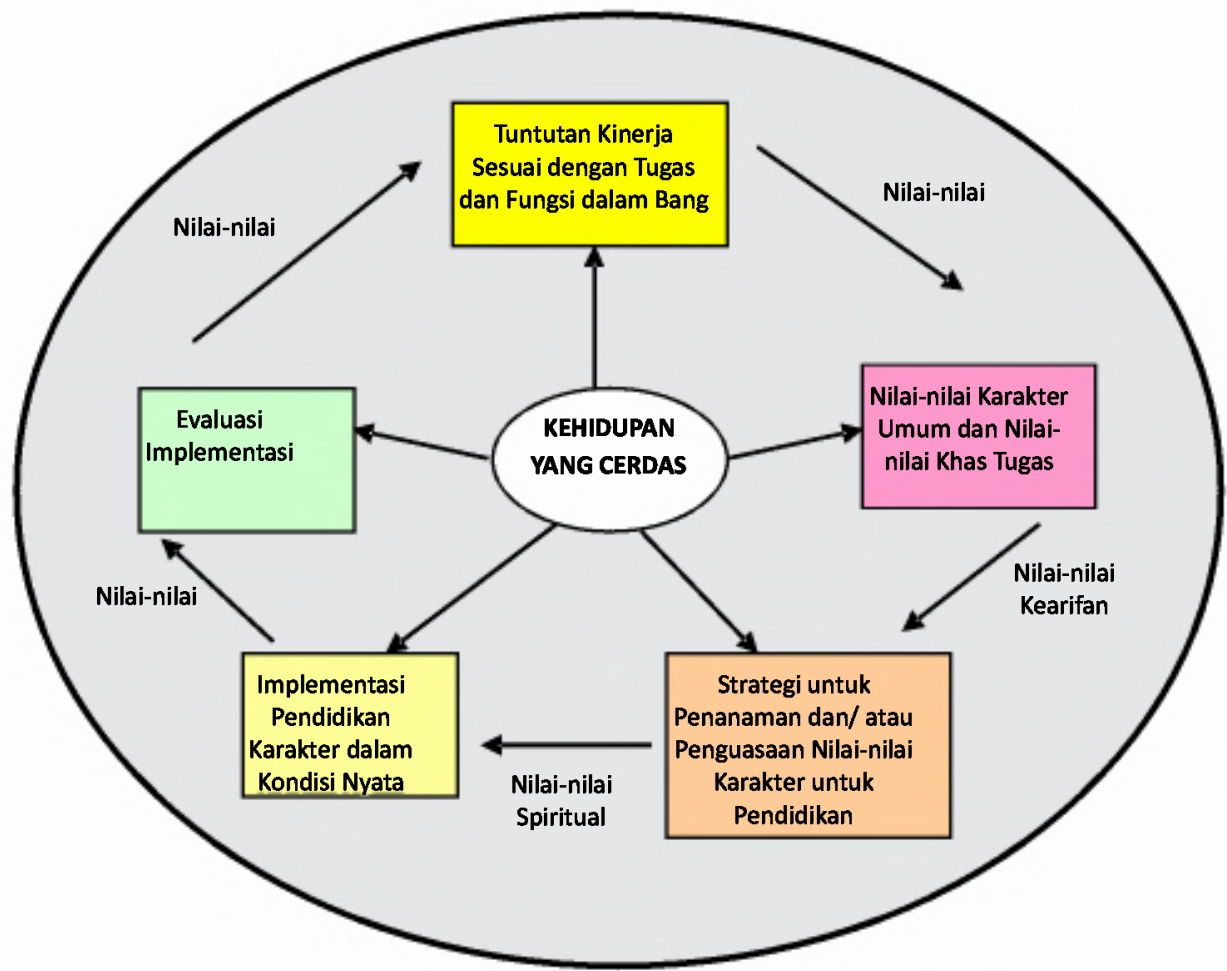

Gambar 1. Siklus implementasi pendidikan karakter

\section{Konsep Pendidikan Karakter}

Secara etimologis, kata karakter (Inggris: character) berasal dari bahasa Yunani (Greek), yaitu charassem yang berarti "to engrave" (Ryan and Bohlin, 1999: 5). Kata "to engrave" bisa diterjemahkan "mengukir," "melukis," "memahatkan," atau "menggoreskan" (Echols dan Shadily, 1995: 214). Dalam Kamus Bahasa Indonesia, kata "karakter" diartikan dengan "tabiat," "sifat-sifat kejiwaan," "akhlak atau budi pekerti yang membedakan seseorang dengan yang lain," dan "watak." Karakter juga bisa berarti "huruf," "angka," "ruang," "simbol khusus yang dapat dimunculkan pada layar dengan papan ketik" (Pusat Bahasa Depdiknas, 2008: 682). Orang berkarakter berarti orang yang berkepribadian, berperilaku, bersifat, bertabiat, atau berwatak.

Dengan makna seperti itu berarti karakter identik dengan kepribadian atau akhlak. Kepribadian merupakan ciri, karakteristik, atau sifat khas diri seseorang yang bersumber dari bentukan-bentukan yang 
diterima dari lingkungan, misalnya keluarga pada masa kecil dan bawaan sejak lahir (Doni Koesoema, 2007: 80). Seiring dengan pengertian ini, ada sekelompok orang yang berpendapat bahwa baik buruknya karakter manusia sudah menjadi bawaan dari lahir. Jika bawaannya baik, manusia itu akan berkarakter baik, dan sebaliknya jika bawaannya jelek, manusia itu akan berkarakter jelek. Jika pendapat ini benar, pendidikan karakter tidak ada gunanya, karena tidak akan mungkin merubah karakter orang yang sudah taken for granted. Sementara itu, sekelompok orang yang lain berpendapat berbeda, yakni bahwa karakter bisa dibentuk dan diupayakan sehingga pendidikan karakter menjadi bermakna untuk membawa manusia dapat berkarakter yang baik.

Secara terminologis, Thomas Lickona (1991: 51), mengemukakan bahwa karakter adalah " $A$ reliable inner disposition to to respons to situations in a morally good way." Selanjutnya Lukona mc "Character no conceived has three interrelated parts: moral knowing, moral feeling and moral behavior". Menurut Lickona, karakter mulia (good character) meliputi pengetahuan tentang kebaikan (moral knowing), lalu menimbulkan komitmen (niat) terhadap kebaikan (moral feeling), dan akhirnya benarbenar melakukan kebaikan (moral behavior). Dengan kata lain, karakter mengacu kepada serangkaian pengetahuan (cognitived), sikap taat (attitudes), dan motivasi (motivations), serta perilaku (behaviors), dan keterampilan (skills).

Dari pengertian di atas dapat dipahami bahwa karakter identik dengan akhlak, sehingga karakter merupakan nilai-nilai perilaku manusia yang universal yang meliputi seluruh aktivitas manusia, baik dalam rangka berhubungan dengan Tuhan, dengan diri sendiri, dengan sesama manusia, maupun dengan lingkungan, yang terwujud dalam pikiran, sikap, perasaan, perkataan, dan perbuatan berdasarkan norma-norma agama, hukum, tata karma, budaya, dan adat istiadat. Dari konsep karakter ini muncul konsep pendidikan karakter (character education). Ahmad Amin (1995: 62), mengemukakan bahwa kehendak (niat) merupakan awal terjadinya akhlak (karakter) pada diri seseorang, jika kehendak itu diwujudkan akan terlihat dalam bentuk pembiasaan sikap dan perilaku.

Program pendidikan karakter pada konteks mikro dapat digambarkan sebagai berikut: 


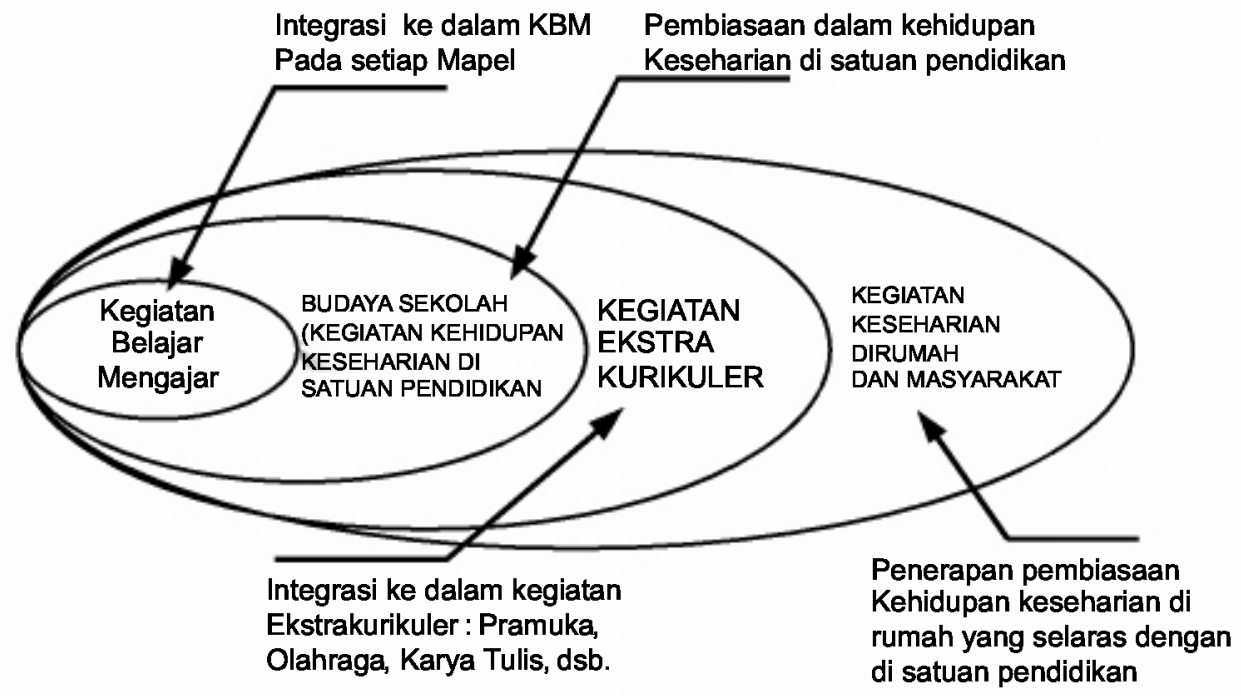

Gambar 2. Konteks mikro pendidikan karakter

Terminologi pendidikan karakter mulai dikenalkan sejak tahun 1900an. Thomas Lickona dianggap sebagai pengusungnya, terutama ketika ia menulis buku yang berjudul The Return of Character Education dan kemudian disusul bukunya, Educating for Character: How Our School Can Teach Respect and responsibility. Melalui buku-buku itu, ia menyadarkan dunia Barat akan pentingnya pendidikan karakter. Pendidikan karakter menurut Lickona mengandung tiga unsur pokok, yaitu mengetahui kebaikan (knowing the good), mencintai kebaikan (desiring the good), dan melakukan kebaikan (doing the good) (Lickona, 1991: 51). Di pihak lain, Frye (2002: 2) mendefinisikan pendidikan karakter sebagai, " $A$ national movement creating schools that foster ethical, responsible, and caring young people by modeling and teaching good character through an emphasis on universal values that we all share".

Jadi, pendidikan karakter harus menjadi gerakan nasional yang menjadikan sekolah sebagai agen untuk membangun karakter siswa melalui pembelajaran dan pemodelan. Melalui pendidikan karakter sekolah harus berpretensi untuk membawa peserta didik memiliki nilainilai karakter mulia seperti hormat dan peduli pada orang lain, tanggung jawab, memiliki integritas, dan disiplin. Di sisi lain pendidikan karakter juga harus mampu menjauhkan peserta didik dari sikap dan perilaku yang tercela dan dilarang. 
Pendidikan harus mampu untuk membentuk manusia secara utuh yang berkarakter, yaitu mengembangkan aspek fisik, emosi, sosial, kreativitas, spiritual, dan intelektual siswa secara optimal. Selain itu, untuk membentuk manusia yang long life learners. Karakter yang berkualitas perlu dibentuk dan dibina sejak dini. Menurut Freud, kegagalan penenaman kepribadian yang baik di usia dini ini akan membentuk pribadi yang bermasalah di masa dewasanya kelak. Kesuksesan orang tua membimbing anaknya dalam mengatasi konflik kepribadian di usia dini sangat menentukan kesuksesan anak dalam kehidupan sosial di masa dewasa kelak (Erikson, 1968).

Proses pembelajaran merupakan bagian yang esensi dari pendidikan. Peraturan pemerintah nomor 19 tahun 2005 bagian kelima pasal 15 tentang standar proses, meliputi hal-hal sebagai berikut: (a) proses pembelajaran pada satuan pendidikan diselenggarakan secara interaktif, inspiratif, menyenangkan, menantang, memotivasi peserta didik untuk berpartisipasi aktif, serta mcmberikan ruang yang cukup bagi prakarsa, kreativitas, dan kemandirian sesuai dengan bakat, minat, dan perkembangan fisik serta psikologis peserta didik; (b) selain ketentuan sebagaimana dimaksud pada ayat (1), dalam proses pembelajaran pendidik memberikan keteladanan, dan; (c) setiap satuan pendidikan melakukan perencanaan proses pembelajaran, pelaksanaan proses pembelajaran, penilaian hasil pembelajaran, dan pengawasan proses pembelajaran untuk terlaksananya proses pembelajaran yang efektif dan efisien (Peraturan Pemerintah, 2005).

Jadi pendidikan karakter tidak hanya mengajarkan mana yang benar dan mana yang salah kepada anak, tetapi lebih dari itu pendidikan karakter menanamkan kebiasaan (habituation) tentang yang baik sehingga peserta didik paham, mampu merasakan. dan mau melakukan yang baik. Dengan demikian, pendidikan karakter membawa misi yang sama dengan pendidikan akhlak atau pendidikan moral. Selanjutnva Frye (2002: 3), menegaskan bahwa pendidikan karakter merupakan usaha yang disengaja untuk membantu seseorang memahami, menjaga, dan berperilaku yang sesuai dengan nilai-nilai karakter mulia.

\section{Pentingnya Implementasi Pendidikan Karakter}

Melihat kondisi riil bangsa Indonesia yang belum solid, kukuh dan terbelah-belah, maka sebagai suatu bangsa yang merdeka dan berdaulat, 
perlu terus mengupayakan terciptanya warga dan bangsa Indonesia yang berkarakter dan berbudaya. Bangsa Indonesia yang memiliki kejelasan dan kebanggaan identitas diri merupakan impian dan cita-cita bagi semua. Bangsa Indonesia yang berkarakter dan berbudaya ditunjukkan dengan perilaku yang berakar dengan agama yang diyakini, budaya yang melatarbelakangi, dan keluhuran tujuan yang dicita-citakan. Dengan demikian setiap individu yang berkarakter seharusnya ditunjukkan dengan perilaku unik sesuai dengan karakteristik kepribadian, nilai-nilai agama yang dianut, dan kondisinya di mana mereka berada. Dalam konteks sebagai warga Indonesia, maka individu itu seharusnya menjunjung tinggi nilainilai ke Indonesiaan dengan tetap menjunjung tinggi nilai-nilai Pancasila, UUD 1945, Bhinneka Tunggal Ika, dan NKRI.

Perkembangan karakter individu pada hakikatnya tidak sama antara yang satu dan lainnya. Hal ini ditegaskan oleh Berkowitz, Marvin W. (Damon: 2002), yaitu:

First, that we have just established that character is a multifaceted phenomenon. Second, the components of character each have their own developmental trajectories. Third, each person develops at a different rate. Fourth, the developmental sequence and profile of the components of character differ in different individuls. Finally, the components of character tend to develop gradually, or in stages for a long period of time.

Perbedaan kecepatan, urutan dan profil perkembangan karakter sangatlah tergantung pada kondisi internal dan eksternal setiap individu, sehingga dalam mengarahkan pengembangan karakter individu yang efektif sangat diperlukan kemampuan mengakomodasikan faktor-faktor yang menyertainya. Perbedaan perkembangan karakter juga berlaku pada usia individu, termasuk pada usia remaja akhir dan dewasa awal (mahasiswa). Latar belakang kehidupan mahasiswa baik di rumah, sekolah maupun masyarakat sangat mempengaruhi perkembangan karakternya. Hal ini diperkuat Thomas Lickona (2002), pengarang Educating for Character, yang menyatakan:

"Moral education is not a new idea. It is, in fact, as old as education itself. Down through history, in countries all over the world, education has had two great goasl, to help young people become smart and to help 
them become good." Good character is not formed automatically, it is developed over time through a sustained process of teaching, example, learning and practice. It is developed through character education.

Semakin jelaslah, bahwa pendidikan karakter begitu penting bagi pembentukan karakter yang baik. Tidaklah mungkin dapat dibentuk karakter yang baik, jika proses pembelajaran itu hanya lebih ditekankan pada kegiatan intelektual. Secara lebih rinci pendidikan karakter juga memiliki kontribusi yang lebih komprehensif, sebagaimana kutipan berikut ini yang diambil dari http://www.icger.org, bahwa:

Quality of character education helps schools create a safe, caring and inclusive learning environment for every student and supports academic development. It fosters qualities that will help students be successful as citizens, in the workplace, and with the academic curriculum. It lays the foundation to help students be successful in all of the goals we have for our public schools. It is the common denominator that will help schools reach all of their goals.

Begitu strategisnya pendidikan karakter, ternyata pendidikan karakter tidak hanya bermanfaat untuk kesuksesan individu dalam proses pendidikan di sekolah atau di kampus, melainkan juga bermanfaat bagi kehidupan individu di tempat kerja dan masyarakat. Lickona (2002), menegaskan bahwa:

Character education as a program that strives to encompas the following, the cognitive, affective, and behavioral aspects of morality. Good character consists of knowing the good, disiring the good and doing the good. Schools must help children understand the core values, adapt or commit to them and then act upon them in their own lives.

Menyadari akan luasnya cakupan pendidikan karakter, yaitu aspek kognitif, afektif, dan perilaku moralitas, sehingga menjadikan individu sebagai pribadi dan warga negara yang baik, maka sekolah maupun universitas bertanggung jawab penuh memberikan bantuan terhadap peserta didik dalam menguasai nilai-nilai moralitas dan kebangsaan, sehingga menjadi warga negara yang baik. 


\section{Identifikasi Pendidikan Karakter di Sekolah}

UNESCO telah melakukan kajian dan memperoleh kesimpulan ada enam dimensi karakter yang bersifat universal. Artinya, agama dan bangsa di manapun mengakui dimensi karakter tersebut. Keenam dimensi karakter ini adalah trustworthiness, respect, responsibility, fairness, caring, and citizenship (Rynders, 2006).

Trustworthiness bisa diterjemahkan dapat dipercaya, apabila seseorang memiliki watak dapat dipercaya berarti orang tersebut memiliki kejujuran, integritas, loyalitas, dan reliabilitas. Dengan kata lain, orang yang memiliki trustworthiness tidak memerlukan lagi pengawasan eksternal. Dimensi kedua respect, merupakan watak yang apabila dimiliki oleh seseorang, maka orang ini dalam melakukan hubungan dengan orang lain senantiasa mendasarkan pada "platinum rule", berbuatlah kepada orang lain sebagaimana orang lain itu mengharapkannya darimu. Dimensi ketiga responsibility, menunjukkan watak bertanggung jawab atas apa yang dilakukan.

Dimensi keempat fairness, memiliki makna senantiasa mengedepankan standar adil, tanpa dipengaruhi oleh sikap dan perasaan yang dimilikinya ketika berhadapan dengan orang lain. Oleh karena itu, dimensi ini berkaitan erat dengan keterbukaan dan objektivitas. Dimensi kelima caring, berkaitan dengan apa yang ada dalam hati dan pertimbangan etika moral manakala menghadapi orang lain. Seseorang yang memiliki watak caring, senantiasa akan mempergunakan kehalusan budi dan perasaan sehingga bisa berempati terhadap kegembiraan atau kepedihan yang dialami orang lain.

Dimensi keenam citizenship, berkaitan dengan watak menjadi warga negara yang baik, yang memahami dan melaksanakan tugas dan tanggung jawab sebagai seorang warga negara. Dimensi ini terjabarkan pada bagaimana perilaku seseorang sebagai warga masyarakat, warga bangsa dan negara yang baik. Indikator warga negara yang baik adalah kepatuhan dan ketaatan pada peraturan dan undang-undang yang berlaku.

Kemudian, kaitannya dengan pendidikan karakter di sekolah, pemerintah dalam hal ini Badan Penelitian dan Pengembangan, Pusat Kurikulum Kementerian Pendidikan Nasional (2011:10), telah merumuskan materi pendidikan karakter yang perlu ditumbuh-kembangkan, yaitu; religius, 
jujur, toleransi, disiplin, kerja keras, kreatif, mandiri, demokratis, rasa ingin tahu, semangat kebangsaan, cinta tanah air, menghargai prestasi, bersahabat atau komunikatif, cinta damai, gemar membaca, peduli lingkungan, peduli sosial, dan tanggung jawab.

\section{Pendidikan Karakter dalam Prespektif Sekolah}

Dalam kaitan dengan membangun jati diri dan identitas diri sebagai suatu bangsa, maka semua komponen bangsa harus mengambil peran, antara lain lewat pendidikan. Sudah barang tentu pendidikan dalam arti yang luas yang dapat diperankan oleh keluarga, media massa, pemerintah, dan lembaga persekolahan atau pendidikan formal.

Pada konteks makro, program pendidikan karakter bangsa dapat digambarkan sebagai berikut: (Kebijaksanaan Nasional Pemerintah RI, 2010).

\section{PENDIDIKAN KARAKTER}

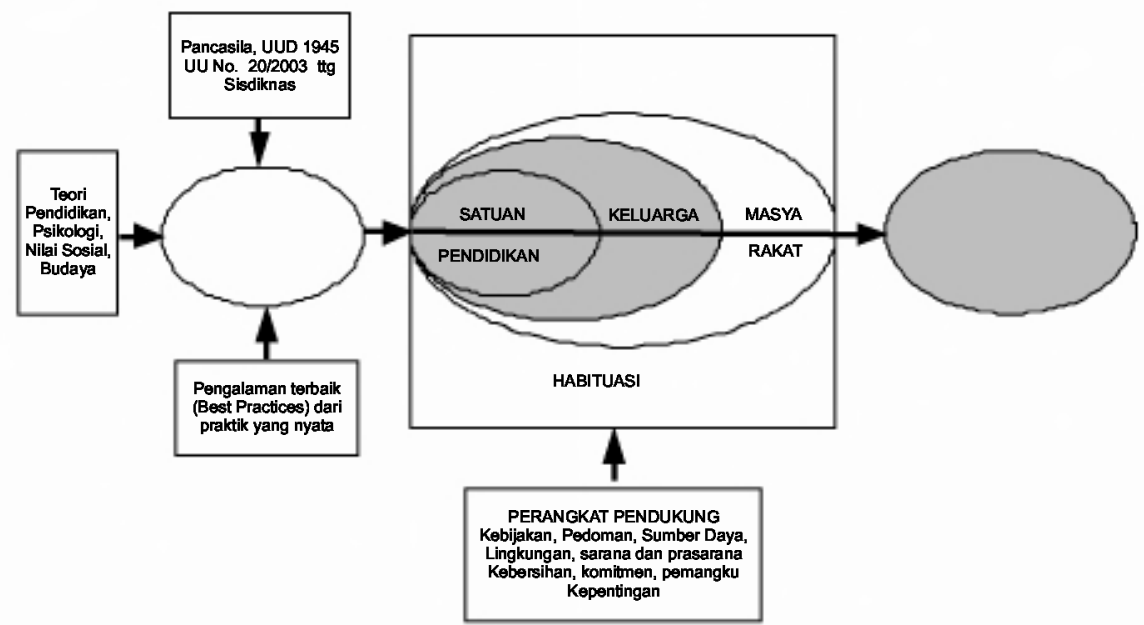

Gambar 3. Konteks makro pendidikan karakter

Sekolah, sebagai lembaga pendidikan formal, memiliki peran penting dalam membangun karakter bangsa. Peran ini dilakukan dengan membekali para peserta didik dengan berbagai pengetahuan dan keterampilan untuk bisa hidup layak dan terhormat di tengah-tengah masyarakat. Di samping itu, pendidikan juga mengembangkan pada diri peserta didik rasa cinta kepada bangsa dan tanah air, yang diekspresikan dalam perilaku mencintai 
hidup bersama dan bekerjasama guna kemajuan bangsanya. Cinta tanah air inilah yang merupakan fondasi lahirnya jiwa patriotisme, yaitu senantiasa siap sedia untuk bekerja demi kebaikan bangsa.

Karakter bangsa ibaratnya tanaman. Bagaimana tumbuh berkembangnya karakter bangsa sangat tergantung dengan kesuburan dan kualitas iklim berbagai komponen yang berperan penting dalam pembangunan karakter, yakni sekolah. Berkaitan dengan ini, suatu penggalan peribahasa menyatakan sebagai berikut: that you cant hare knowledge without character. You can't build character without a whole school and a whole village, and we must recognize that tomorrow's villages will be built by today's children.

\section{Strategi Pendidikan Karakter}

Dalam membentuk karakter, ada beberapa langkah yang perlu diperhatikan, yaitu: (1) memasukkan konsep karakter pada setiap kegiatan pembelajaran dengan cara menanamkan nilai kebaikan kepada anak (knowing the good); (2) menanamkan konsep diri pada anak setiap akan memasuki materi pelajaran baik itu dalam dalam bentuk janji tentang karakter, maupun pemahaman tentang makna karakter yang akan disampaikan; (3) memberikan beberapa contoh, misalnya melalui cerita dengan tokohtokoh yang mudah dipahami siswa; (4) mengembangkan sikap mencintai perbuatan baik (loving the good); (5) melaksanakan perbuatan baik (acting the good). Karakter yang sudah dimulai dibangun melalui konsep diaplikasikan dalam proses pembelajaran selama di sekolah, dan; (6) membuat slogan yang mampu menumbuhkan kebiasaan baik dalam segala tingkah laku masyarakat sekolah. Beberapa slogan untuk membangun kebiasaan, misalnya: "Kebersihan sebagian dari iman," "Kebersihan pangkal kesehatan."

Pendidikan karakter tidak bisa hanya diceramahkan, atau dipaksakan lewat proses indoktrinasi berselubung pendidik. Pendidikan karakter perlu didasarkan pada strategi yang tepat. Kevin Ryan (2002: 5 Mei 2011), salah seorang pedagog berkebangsaan Amerika, mengembangkan strategi pendidikan karakter yang disebut dengan enam "E". yaitu: Example, explanation, exhortation, ethical environment, expedience, dan expecation of excellence. 
Menurut strategi Ryan tersebut, pendidikan karakter memerlukan contoh atau tauladan, jadi peserta didik memiliki model yang ditiru. Sesuatu yang akan ditiru oleh siswa, disertai dengan pengetahuan mengapa seseorang perlu melakukan apa yang ditiru tersebut. Untuk itu perlu ada penjelasan mengapa sesuatu harus dilakukan, sehingga tidak meniru membabi buta, melakukan sesuatu itu harus secara serius sungguhsungguh, sebagai bentuk kerja keras dan serius, tidak kenal kata lelah. Dalam melaksanakan sesuatu itu harus mempertimbangkan lingkungan baik sosial maupun fisik. Artinya, seseorang harus sensitif atas kondisi dan situasi yang ada di sekitarnya.

Adapun strategi yang penulis tawarkan adalah: Pertama, tujuan, sasaran, dan target yang akan dicapai harus jelas dan konkret. Kedua, pendidikan karakter akan lebih efektif dan efisien kalau dikerjakan tidak hanya oleh sekolah, melainkan harus ada kerjasama antara sekolah dengan orang tua siswa. Ketiga, menyadarkan pada semua guru akan peran yang penting dan bertanggung jawab dalam keberhasilan melaksanakan dan mencapai tujuan pendidikan karakter. Lewat mata pelajaran yang diampu atau tugas yang menjadi tanggung jawabnya, harus mengembangkan karakter pada diri peserta didik. Untuk itu guru harus benar-benar memahami filosofi seorang guru, tidak sekedar tekhnis melaksanakan pembelajaran.

Keempat, kesadaran guru akan perlunya "hidden curriculum", merupakan instrumen yang amat penting dalam pengembangan karakter peserta didik. Kurikulum tersembunyi ini ada pada perilaku guru, khususnya dalam berinteraksi dengan para peserta didik, yang disadari atau tidak akan berpengaruh besar pada diri peserta didik. Kelima, dalam melaksanakan pembelajaran guru harus menekankan pada daya kritis dan kreatif peserta didik (critical and creative thinking), kemampuan bekerja sama, dan keterampilan mengambil keputusan. Metode pembelajaran yang paling tepat untuk mencapai tujuan tersebut adalah cooperative learning dan problem based teaching and beaming.

Keenam, kultur sekolah harus dimanfaatkan dalam pengembangan karakter peserta didik. Nilai-nilai, keyakinan-keyakinan, norma-norma, semboyan- semboyan sampai kondisi fisik sekolah yang ada perlu dipahami dan didesain sedemikian rupa sehingga fungsional untuk mengembangkan karakter siswa. Amat menarik untuk dicatat suatu temuan 
penelitian menyimpulkan bahwa hasil test terstandar pada sekolah-sekolah di California selama tahun 1999 sampai 2002 secara signifikan berkorelasi positif dengan kemampuan sekolah menciptakan kultur sekolah berupa " $a$ clean and safe physical environment" (Traub, 2005: 4).

Ketujuh, pada hakikatnya salah satu fase pendidikan karakter adalah merupakan proses pembiasaan dalam kehidupan sehari-hari, khususnya di sekolah yang dapat dimonitor dan dikontrol oleh kepala sekolah dan guru. Diharapkan orang tua siswa juga memonitor dan mengontrol perilaku sehari-hari peserta didik di lingkungan keluarga dan masyarakat.

\section{Model Pendidikan Karakter di Sekolah}

Model merupakan suatu gambaran dan pola bagaimana proses pendidikan karakter dilaksanakan. Model diawali dengan menentukan dan mendeskripsikan sasaran dan target yang akan dicapai, yang bersifat memiliki makna (meaningfull), dapat diukur (measurable) dan berkelanjutan (sustainable). Bermakna artinya memiliki substansi bagi para peserta didik, tidak cukup hanya dihafal dan diketahui, tetapi mengandung sesuatu yang rasional dan memberikan kesan mendalam bagi mereka. Dapat diukur memiliki arti bahwa seberapa tinggi atau seberapa besar atau seberapa dalam hasil yang dicapai pendidikan karakter harus dapat diketahui. Termasuk harus dapat diketahui bagaimana perkembangan hasil dari satu waktu ke waktu berikutnya. Berkelanjutan memiliki arti bahwa hasil dari pendidikan karakter bersifat dinamis, menarik dan dapat secara terus menerus diperbaharui dan ditingkatkan.

Kemudian juga harus konsisten, yaitu berarti bahwa aspek karakter yang akan dikembangkan pada diri peserta didik harus menjadi kebiasaan yang dilakukan secara terus-menerus oleh para pendidik. Hal ini amat penting, karena begitu pendidik tidak satu kata dengan perbuatan, dalam aspek karakter yang akan dikembangkan, maka sulit hal tersebut dikembangkan pada diri peserta didik. Konsistensi pendidik untuk meneladankan karakter yang akan dikembangkan pada diri peserta didik akan sangat mempengaruhi keberhasilan program pendidikan karakter. Dengan kata lain pendidik harus memiliki integritas dalam melaksanakan pendidikan karakter ini. 
Dalam pendidikan karakter juga harus kreatif. Kreatif memiliki arti bahwa pendidik dalam melaksanakan pembelajaran harus dapat menjelaskan suatu aspek karakter tidak hanya sebatas menyampaikan pengertiannya saja, melainkan menjelaskan berbagai contoh yang menarik bagi peserta didik. Berbagai pengalaman, khususnya pengalaman para tokoh atau pahlawan, bagi peserta didik sangat penting dan pada umumnya berhasil memberikan makna pada diri peserta didik. Kreativitas ini diperlukan untuk mengembangkan imajinasi peserta didik berkaitan dengan berbagai aspek karakter yang akan dikembangkan pada diri peserta didik.

Selain itu, pendidikan karakter juga harus bersifat konkrit. Konkrit memiliki makna bahwa nilai-nilai yang akan disampaikan harus dijabarkan dan direfleksikan secara eksplisit dan relevan dengan kondisi dan situasi yang ada. Hal ini penting untuk menghindari terjadinya ambivalensi atas sesuatu isi karakter yang akan dikembangkan. Dalam kaitan inilah pentingnya pendidik untuk senantiasa membahas sesuatu yang abstrak dikaitkan dengan realitas kehidupan masyarakat.

Model komprehensif pendidikan karakter yang dikembangkan oieh IHF adalah sebuah model yang melakukan pendidikan karakter dengan menggunakan metode pendidikan karakter secara eksplisit dan bersifat komprehensif. Model ini telah diujicobakan melalui pilot project SBB dan TK karakter (untuk usia dini) yang terlihat efektif dalam membentuk karakter anak, yaitu: (1) memakai acuan nilai-nilai yang tertuang ke dalam sembilan pilar karakter yang direfleksikan ke dalam modul kegiatan di kelas; (2) mengajarkan pilar-pilar dalam kurun waktu dua tahun sekolah, di mana tema setiap pilar ditukar secara bergantian setiap dua atau tiga minggu sekali; (3) menggunakan kurikulum karakter (kurikutum eksplisit), yang diterapkan dengan refleksi pilar setiap hari selama 20 menit sebelum kelas dimulai, yaitu dengan menerapkan prinsip knowing the good, loving the good, and desiring the good; (4) menggunakan sistem "pembelajaran terpadu berbasis karakter" (character based integrated learning system). Pilar karakter diintegrasikan pada pembelajaran di sentra-sentra (TK) atau seluruh mata pelajaran (Sekolah Dasar). Dengan cara ini penanaman karakter akan lebih efektif' karena dalam seluruh kegiatan belajar di kelas akan mengandung pula nilai-nilai karakter melalui latihan dan pengalaman konkrit (moral action); (5) menggunakan teori developmentally appropriate 
practices dan teori multiple intelligences (kecerdasan majemuk), metode pembelajaran inquiry-based learning (pendekatan yang merangsang daya minat anak), dan cooperative larning (pendekatan belajar bersama dalam kelompok) sehingga tercipta suasana belajar yang menyenangkan (termasuk sistem aktivitas sentra, dan unit-unit tema). dan; (6) menerapkan co-parenting di mana orang tua dikirimkan surat pemberitahuan setiap awal pilar dimulai agar mereka tahu bahwa anaknya sedang belajar pilar di sekolah. Orang tua dihimbau untuk menerapkan serangkaian aktifitas di rumah (diberikan daftar aktifitas), dan diwajibkan mengisi kuesioner pada akhir pilar tentang pengalaman dan apa yang dirasakan orang tua ketika mengajarkan pilar di rumah. Selain untuk melibatkan orang tua siswa, pengisian kuisioner bisa dijadikan bahan evaluasi bagi sekolah untuk melihat efektivitas pendidikan karakter yang sedang dilakukannya.

Karakter yang akan dikembangkan pada diri peserta didik adalah untuk dijadikan pedoman dan dipraktekkan dalam kehidupan seharihari. Artinya, pada diri peserta didik ada proses mulai dari mendengar atau melihat, memahami, menyadari, dan mengambil keputusan untuk melakukannya. Dalam kaitan ini ada tiga aspek yang perlu dikaji. Aspek pertama komitmen, yang memiliki arti senantiasa ingin melaksanakan sesuatu dengan baik dan benar. Aspek kedua adalah kesadaran, yang merupakan dimensi moral yang dimiliki seseorang untuk memahami dan menerima serta menentukan pilihan-pilihan dalam situasi yang konkret dengan mendasarkan pada aturan yang ada.

\section{Penutup}

Pelaksanaan pendidikan karakter adalah melalui suri teladan sehingga para peserta didik akan menirukan seperti yang dilakukan pemimpin, dan guru. Untuk itu, pendidikan karakter akan berhasil jika dimulai dari pembiasaan kepada para guru dan kepala sekolah. Dengan kata lain, pendidikan karakter akan berhasil jika dilakukan melalui pola top-down, maka menjadi naif sekiranya siswa dituntut untuk berkarakter, tetapi para guru dan pemimpinnya justru tidak berkarakter. Dengan demikian, mari dengan kesadaran penuh para guru dan kepala sekolah agar dapat sebagai panutan bagi peserta didik dalam hal nilai-nilai karakter. 
Pendidikan karakter membentuk aspek pribadi peserta didik secara utuh, yaitu aspek jasmani, rohani, makhluk sosial, dan aspek makhluk Tuhan. Indikator keberhasilan pendidikan karakter di sekolah terangkum dalam domain afektif dan domain sosial. Untuk itu, seyogyanya dalam pembelajaran domain afektif dan sosial harus mendapatkan porsi yang seimbang dengan domain kognitif dan psikomotor. Diharapkan jika keempat domain dikuasai secara menyeluruh oleh peserta didik, akan terbentuk manusia Indonesia seutuhnya.

\section{Daftar Pustaka}

Damon, William. (Ed). (2002). Bringing in a new era in character education. California: Hoover institution press.

Lickona, T., Schaps, E., \& Lewis, C. (2002). Eleven principles of effective character education. Washington DC: character education partnership.

Gholar, C. (2004). Character education: creating a framework for excellence. Urban programs resource network, retrieved. http:// www.urbanext.uiuc.edu,on 5 may 2011.

Kementerian Pendidikan Nasional, Badan Penelitian dan Pengembangan, Pusat Kurikulum. (2011). Pengembangan pendidikan budaya dan karakter bangsa pedoman sekolah.

Kevin, Ryan. (2002). The six e's of character education, retrieved. From // www.bu.edu/education/caec/files/6E.htm.

Rynders. L. (2006). If you matter to some one. There is always a glimmer of hope. Reclaiming children \& youth, 14 (4), 215, 217 retrieved from academic search complete: 19719036.

Tracub, James. (2005). The moral imperative, character education soul by soul, at the hyde schools. Education next, winter, vol. 5, 2005, no. 1: $P$.

Erikson, E. H. (1968). Identity: Youth and crisis. New York: Norton.

Peraturan Pemerintah. (2005). Peraturan pemerintah nomor 19 tahun 2005 tentang standar nasional pendidikan. 
Undang-undang. (2003). Undang-undang sistem pendidikan nasional tahun 2003.

Ahmad Amin. (1995). Etika (Ilmu Akhlak). Terjemahan. Farid Ma'ruf. Jakarta: Bulan Bintang. Cetakan VIII.

Doni Koesoema A. (2007). Pendidikan karakter: Strategi mendidik anak di zaman global. Cetakan I. Jakarta: Grasindo.

Bohlin, K, D. Farmer \& K Ryan(2001). Building character in schools: Resource Guide.California: Joossey Bass

Zamroni. (2011). Dalam Darmiyati edt. Strategi dan model implementasi pendidikan karakter di sekolah. UNY Press. Yogyakarta.

Echols, M. John dan Hassan Shadily. (1995). Kamus Inggris Indonesia: an English-Indonesian Dictionary. Jakarta: PT. Gramedia. Cetakan XXI.

Frye, Mike at all. (Ed). (2002). Character education: information al handbook and guide for support and implementation of the student citizent act of 2001. North Carolina: Public Schools of North Carolina.

Lickona, Thomas. (1991). Educating for character: how our school can teach respect and responsibility. New York, Toronto, London, Sydney, Aucland: Bantam Books.

Toto Cholik Mutohir. (2002). Fungsi sosial olahraga dalam konteks national and character building. Makalah yang disajikan dalam seminar nasional olahraga dan integrasi bangsa, 4 September 2002. Jakarta: Ditjora, Depdiknas, Lemhanas, Korpri dan Isori.

Weinberg, Robert S and Gould, Daniel. (2002). Foundations of sport and exercise psychology. 3rd edition. Champaign, IL: Human Kinetics.

Chasan, Barry. (1985). Contemporary approaches to moral education. New York: Teacher College Press.

Hancock, Dorothea W. (2009). The role of narrative research in moral education. Interdiscilinary: Perspective on moral education. The 2009 APNME Conference. Seoul National University. 
Moon, Yong-Lin. (2009). An agenda we have forgetten: corruption. The 2009 APNME Conference. Seoul National University.

Reimer, Joseph, Paolitto, Diana Pritchard, Hers, Richard H. (1983). Promoting moral growth from piaget to kohlberg. New York \& London: Longman.

Zuchdi, Darmiyati. (2002). Pendidikan karakter dalam perspektif teori dan praktik. Yogyakarta: UNY Press.

..(2008). Humanisasi pendidikan: Menemukan kembali pendidikan yang manusiawi. Jakarta: Bumi Aksara.

..(2008). Pendidikan karakter, Grand Design dan Nilai-nilai Target. Yogyakarta: UNY Press. 